\title{
Determination of flavones in species of Thymus L. (Lamiaceae) from Macedonian flora
}

\author{
Svetlana Kulevanova ${ }^{1 *}$, Marina Stefova ${ }^{2}$, Tatjana Kadifkova Panovska ${ }^{1}$, \\ Jasmina Tonic ${ }^{1}$, Trajce Stafilov ${ }^{2}$ \\ ${ }^{1}$ Faculty of Pharmacy, Vodnjanska 17, 1000 Skopje, R Macedonia \\ ${ }^{2}$ Instute of Chemistry, Faculty of Science, P. O. Box 162, 1000 Skopje, R Macedonia
}

Received October 2001; accepted March 2002

\begin{abstract}
Assay of flavonoids in extracts of seven Thymus L. (Lamiaceae) species from Macedonia including identification and quantification was performed. Extracts obtained after hydrolysis of air dried samples $\left(\mathrm{A}_{1}\right)$ were analyzed by thin layer chromatography (TLC) and high performance liquid chromatography (HPLC). Luteolin and apigenin were identified in comparison to authentic standard substances. The content of total flavonoids in plant samples determined by UV-Vis spectrometry (with $\mathrm{AlCl}_{3}$ ) ranged from 0.05-0.13 \%. Two other extracts were prepared by extraction with a mixture of ethanol:water (7:3, V/V), evaporation until only water remained and extraction first with diethylether $\left(A_{2}\right)$ and secondly with ethyl acetate $\left(A_{3}\right)$. The content of flavonoids in diethyl-ether and ethyl acetate extracts ranged from $52.5-244.4 \mathrm{mg} \cdot \mathrm{ml}^{-1}$ and $48.7-117.5 \mathrm{mg} \cdot \mathrm{ml}^{-1}$, respectively. For quantification of luteolin and total flavonoids the HPLC method was applied, using reverse phase column C18, mobile phase consisting of $5 \%$ acetic acid and methanol in gradient elution mode and column temperature set to $40{ }^{\circ} \mathrm{C}$. The content of luteolin in the plant samples ranged from $0.23-0.48 \%$ (m/m), while the content of total flavonoids was found to be $0.26-0.52 \%$.
\end{abstract}

Key words: Thymus, flavones, identification, determination, HPLC analysis

\section{Introduction}

Certain biological and pharmacological effects of the Thymus species have been experimentally proved, such the expectorant (1), spasmolytic (1-3), antibacterial (1,4), antifungal (5), antioxidant (6-9), etc. These activities are due to the specific composition of the essential oils (1, 4-9), flavonoids (1-3, 9), phenolic acids (4) and other chemical constituents of Thymus.

Beside the data concerning the composition of the essential oils, a lot of literature data about Thymus also consider information about the flavonoids present in this species. A very comprehensive work is presented in the papers of Spanish authors where the distribution of flavone aglycones in a number of Thymus species is given (10-15). The flavonoids have also been investigated in representatives of Macedonian
Thymus species, and luteolin, apigenin, diosmetin, eriodyctiol and naringenin were identified as free flavonoid aglycones in many of them (16-18).

In respect to the literature data, a lot of information on the identification and isolation of flavonoids is available, which cannot be said for quantitative data on these components of Thymus. Determination of their content could be important because the flavonoids are involved in spasmolytic, antioxidant and other activities of Thymus sp. The aim of the present study is to establish methods for determining the total flavonoid content as well as the content of the main flavone aglycones in Macedonian Thymus species.

*e-mail: svetlana.kulevanova@baba.ff.ukim.edu.mk

tel: 126-032, fax: 123-054 


\section{Experimental}

\section{Plant material}

Aerial parts of the plant were collected in the flowering season during summer 1997 and 1998 in different parts of Macedonia. The material was air dried, packed in paper bags and kept in a dark and cool place until analysis. The identity of plant species was verified by Prof. Dr. V. Matevski from the Institute of Biology, Faculty of Science in Skopje as follows:

1. Thymus tosevii ssp. tosevii var. tosevii Vel.; Kichevo, western Macedonia, 1997

2. Thymus tosevii ssp. tosevii var. longifrons Ronn.; Mavrovo, western Macedonia, 1997

3. Thymus tosevii ssp. tosevii var. degenii Ronn.; Lazaropole, western Macedonia, 1998

4. Thymus macedonicus (Deg. et Ur.) Ronn.; Berovo, eastern Macedonia; 1998

5. Thymus moesiacus Vel.; Shar Planina, northern Macedonia, 1997

6. Thymus alsarensis Ronn.; Kozjak Mountain, southern Macedonia, 1998

7. Thymus longidens var. lanicaulis Vel.; Skopje, central Macedonia, 1998

\section{Reagents and authentic samples}

The reagents used were of highest purity ( $>99.95$ purity), methanol HPLC grade, glacial acetic acid (Merck, Darmstadt, Germany) and authentic samples of apigenin, luteolin, naringenin, eriodyctiol, chrysoeriol and diosmetin (Extrasynthese, Lyon, France).

\section{Apparatus}

A Perkin-Elmer UV-Vis spectrometer Lambda 16 for spectrometric measurements and a Varian HPLC system equipped with a ternary pump Model 9012 and UV-diode-array detector Model 9065 for liquid chromatography measurements were used.

\section{Extraction procedure}

Extract $A_{1}$. Plant material $(1 \mathrm{~g})$ was extracted with $60 \mathrm{ml}$ acetone and $2 \mathrm{ml} 25 \% \mathrm{HCl}$ in an erlenmeyer flask (with condensator) on a water bath with continuous mixing, $40 \mathrm{~min}$. The mixture was then cooled, filtered and transferred to a 100 $\mathrm{ml}$ volumetric flask and the operation was repeated with $40 \mathrm{ml}$ acetone, $20 \mathrm{~min}$. After filtration in the same flask, it was filled with acetone to volume. $40 \mathrm{ml}$ of the solution was transferred into a separating funnel, $50 \mathrm{ml}$ of water was added and the extraction was repeated twice with $20 \mathrm{ml}$ and a third time with $15 \mathrm{ml}$ ethylacetate. The ethylacetate fractions were collected and washed three times with $50 \mathrm{ml}$ of water each, then dried with anhydrous $\mathrm{Na}_{2} \mathrm{SO}_{4}$ for 30 min, filtered into a 50 ml volumetric flask and filled with ethylacetate to volume.

Extracts $A_{2}$ and $A_{3} .10 \mathrm{~g}$ of plant material were extracted with an ethanol : water mixture $(7: 3, \mathrm{~V} / \mathrm{V})$ at room temperature, with continuous mixing for $24 \mathrm{~h}$. After filtration the solution was evaporated under low pressure until water remained only. The water phase was transferred into a separating funnel and extracted first with ether and then with ethylacetate. The obtained extracts, in ether and in ethylacetate, were evaporated to dryness and the residues were dissolved in $10 \mathrm{ml}$ of methanol, giving the extracts marked $A_{2}$ and $A_{3}$, respectively.

The extracts $A_{1}, A_{2}$ and $A_{3}$ were used for identification (TLC) and determination of total flavonoids (by spectrophotometry).

Extract B: Plant material (2.0 g) was extracted with acetone and $2 \mathrm{ml} 25 \% \mathrm{HCl}$ using the same procedure as described for extract $\mathrm{A}_{1}$. A $25 \mathrm{ml}$ portion of this acetone extract was transferred to a separating funnel. $50 \mathrm{ml}$ of water was added and extraction with ethylacetate was repeated until a negative reaction on flavonoids was obtained (test with TLC in system $\mathrm{S}_{1}$ ). The ethylacetate extracts were collected and washed three times with $100 \mathrm{ml}$ of water, dried with anhydrous $\mathrm{Na}_{2} \mathrm{SO}_{4}$ for $30 \mathrm{~min}$, filtered and evaporated to dryness under low pressure. The residue was dissolved in $10 \mathrm{ml}$ of methanol and the solution was used for identification and determination of flavone aglycones by HPLC.

\section{Identification of flavonoids}

Flavone aglycones were identified by TLC and HPLC methods compared to authentic samples of flavonoids.

TLC. Commercial TLC aluminium sheets with Silica $\mathrm{HF}_{254}$ and the following mobile phases were used:

$\mathrm{S}_{1}$ : Toluene:EtAcO:HCOOH = 58:33:9 (V/V);

$\mathrm{S}_{2}: \mathrm{CHCl}_{3}: \mathrm{MeOH}=97: 3(\mathrm{~V} / \mathrm{V})$;

$\mathrm{S}_{3}$ : Benzene:dioxane: $\mathrm{AcOH}=$ 90:25:4 (V/V).

The visualization of the spots was performed under UV light at 254 and $366 \mathrm{~nm}$ before and after spraying with $\mathrm{AlCl}_{3}$ solution.

HPLC. A reverse phase column C18 ( 250 x 4.6 mm, 5 mm particles) was used. The mobile phase consisted of two solvents: $5 \% \mathrm{CH}_{3} \mathrm{COOH}(\mathrm{A})$ and $\mathrm{CH}_{3} \mathrm{OH}(\mathrm{B})$ and the elution program for screening the extracts was the following: 0-5 min $70 \% \mathrm{~A} ; 10-15$ $\min 60 \%$ A; 20-25 min $50 \%$ A; 30-35 min $40 \%$ A and 40-45 $\min 20 \% \mathrm{~A}$. The flow rate was $1.3 \mathrm{ml} / \mathrm{min}$ and the temperature was set to $30^{\circ} \mathrm{C}$. The elution was monitored at 254 and $348 \mathrm{~nm}$.

\section{Determination of flavonoids}

Spectrophotometry: UV-Vis spectrophotometry was used for determination of total flavonoids. Luteolin was used for the construction of the calibration curve in the concentration range from 1.0-10.0 mg $\cdot \mathrm{ml}^{-1} .10 \mathrm{ml}$ of extract $\mathrm{A}_{1}$ was transferred into a $25 \mathrm{ml}$ volumetric flask, $1 \mathrm{ml} 2 \% \mathrm{AlCl}_{3}$ was added and the solution was filled to volume with methanol-acetic acid. After 30 min the absorbance was measured at $390 \mathrm{~nm}$ against the same solution without $\mathrm{AlCl}_{3}$ being blank.

The contents of flavonoids were determined in extracts $\mathrm{A}_{2}$ and $\mathrm{A}_{3}$. The whole procedure for obtaining the hydrolyzed 
Table 1. TLC and HPLC identification of flavonoids in different Thymus species, after hydrolysis

\begin{tabular}{|c|c|c|c|c|}
\hline & $\mathrm{S}_{1}^{*}$ & $\mathrm{~S}_{2} *$ & $\mathrm{~S}_{3} *$ & $t_{R} / \min (\mathrm{HPLC})$ \\
\hline \multicolumn{5}{|l|}{ Extracts } \\
\hline Thymus tosevii ssp. tosevii var. tosevii Vel. & $0.28 ; 0.52 ; 0.63$ & $0.32 ; 0.47 ; 0.58$ & $0.38 ; 0.52 ; 0.73$ & $4.10 ; 8.90 ; 15.43$ \\
\hline Thymus tosevii ssp. tosevii var. longifrons Ronn. & $0.28 ; 0.51 ; 0.62$ & $0.32 ; 0.48 ; 0.58$ & $0.38 ; 0.52 ; 0.72$ & $4.15 ; 8.90 ; 15.50$ \\
\hline Thymus tosevii ssp. tosevii var. degenii Ronn. & $0.28 ; 0.52 ; 0.63$ & $0.32 ; 0.46 ; 0.59$ & $0.38 ; 0.52 ; 0.72$ & 4.08; 8.72; 15.48 \\
\hline Thymus macedonicus (Deg. et Ur.) Ronn. & $0.27 ; 0.51 ; 0.63$ & $0.32 ; 0.47 ; 0.58$ & $0.38 ; 0.51 ; 0.73$ & $4.07 ; 8.90 ; 15.40$ \\
\hline Thymus moesiacus Vel. & $0.28 ; 0.52 ; 0.63$ & $0.32 ; 0.46 ; 0.57$ & $0.38 ; 0.50 ; 0.73$ & $4.10 ; 8.93 ; 15.60$ \\
\hline Thymus alsarensis Ronn. & $0.26 ; 0.50 ; 0.61$ & $0.32 ; 0.47 ; 0.59$ & $0.38 ; 0.51 ; 0.72$ & $4.12 ; 8.91 ; 15.50$ \\
\hline Thymus longidens var. lanicaulis Vel. & $0.27 ; 0.52 ; 0.62$ & $0.32 ; 0.47 ; 0.58$ & $0.38 ; 0.50 ; 0.72$ & $4.10 ; 8.75 ; 15.40$ \\
\hline \multicolumn{5}{|l|}{ Standard substances } \\
\hline Luteolin & 0.52 & 0.33 & 0.51 & 8.86 \\
\hline Apigenin & 0.62 & 0.58 & 0.73 & 15.51 \\
\hline Diosmetin & 0.58 & 0.61 & 0.85 & 17.22 \\
\hline Chryseriol & 0.60 & 0.67 & 0.85 & - \\
\hline Caffeic acid & 0.27 & 0.46 & 0.38 & 3.20 \\
\hline
\end{tabular}

* $R f$ values of the spots; $\mathrm{S}_{1}$ : Toluene:EtAcO:HCOOH = 58:33:9; $\mathrm{S}_{2}: \mathrm{CHCl}_{3}: \mathrm{MeOH}=97: 3 ; \mathrm{S}_{3}:$ Benzene:Dioxane:AcOH = 90:25:4 (V/N).

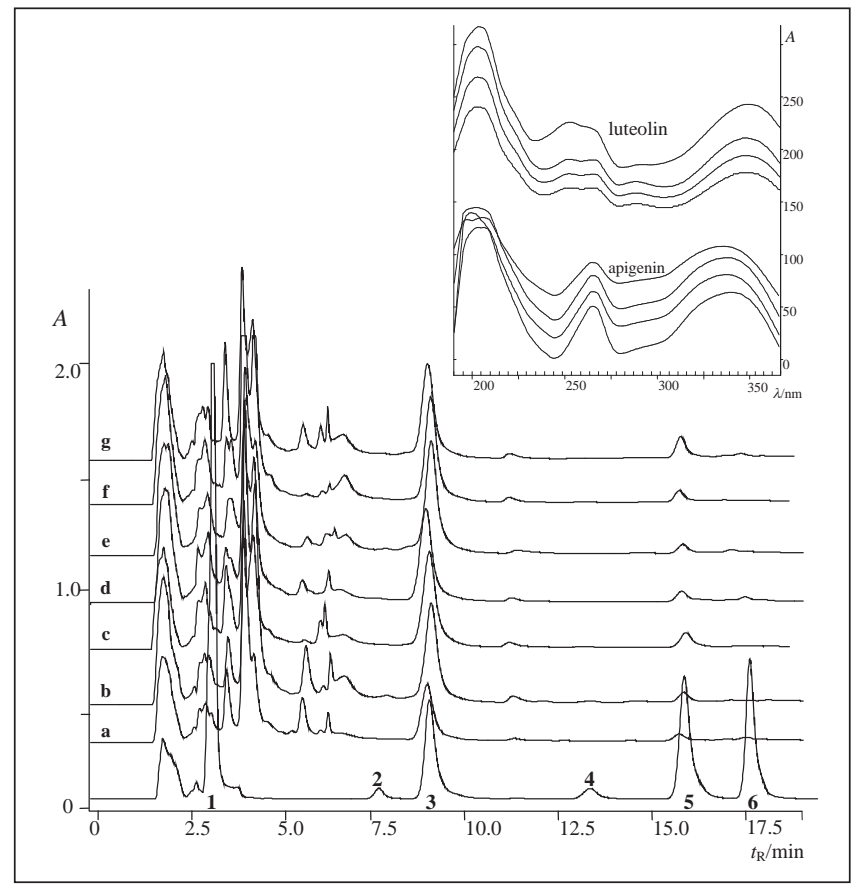

Fig 1. HPLC chromatograms of: mixture of standard substances and hydrolysed extracts of: a. Thymus longidens var. lanicaulis; b. Thymus alsarensis; c. Thymus moesiacus; d. Thymus tosevii var. degenii; e. Thymus tosevii var. longifrons; f. Thymus macedonicus, g. Thymus tosevii var. tosevii, with the UV-spectra of the dentified flavones luteolin and apigenin. (1-caffeic acid, 2-eriodyctiol, 3-luteoilin, 4-naringenin, 5-apigenin, 6-diosmetin)

extracts (described for $A_{1}$ ) was repeated taking $1 \mathrm{ml}$ of the corresponding extracts, instead of $1 \mathrm{~g}$ of plant material.

HPLC. The experimental conditions were the same as those described for the identification. The same stationary and mobile phases were used, but the elution program for quantifying luteolin in the extracts was much shorter, as follows: 0-15 min $45 \% \mathrm{~A}$ and $20-30 \mathrm{~min} 20 \% \mathrm{~A}$. The flow rate was $0.8 \mathrm{ml} \cdot \mathrm{min}-1$ and the temperature was set to $40{ }^{\circ} \mathrm{C}$. The data acquisition was made at $348 \mathrm{~nm}$. Calibration was made in the concentration range of $0.05-1 \mathrm{mg} \cdot \mathrm{ml}^{-1}$ luteolin in methanol, or expressed in terms of mass of luteolin injected into the column from 1-20 $\mu \mathrm{g}$ luteolin (sample loop $20 \mu \mathrm{l}$ ).

\section{Results and discussion}

\section{Identification of flavonoids}

The flavone aglycones were identified in the extracts obtained after hydrolysis of flavone glycosides in drugs using $\mathrm{HCl}$. The results of TLC and HPLC qualitative analysis are presented in Table 1.

Two dark violet spots were recognized under UV light (366 $\mathrm{nm}$ ), which become clear yellow to orange-yellow after spraying with $\mathrm{AlCl}_{3}$ solution. The $R f$ values of these spots in different solvent systems were very close to the ones obtained for authentic samples of luteolin and apigenin. The third light blue spot before and after spraying with $\mathrm{AlCl}_{3}$ was identified as caffeic acid. The HPLC screening method confirmed the presence of a significant quantity of luteolin and a much smaller quantity of apigenin, which were identified according to the retention times and the UV spectra, compared to those for authentic samples (Fig. 1).

Determination of total flavonoids by spectrophotometry

The method is based on the formation of stable complexes of $\mathrm{Al}^{3+}$ ions with $\mathrm{OH}$-groups in $\mathrm{C}-3$ or $\mathrm{C}-5$ position together with the carbonyl group in the $\gamma$-pirone ring of flavones and flavonols in a

Макед. фарм. билт., 47, (1,2) 9-14 (2001) 
acidic medium. The products of the reaction have maximal absorption at $425 \mathrm{~nm}$ in the case of flavonols and at $390 \mathrm{~nm}$ when flavones are present $(19,20)$. In our examination luteolin was used for the construction of a calibration curve in the concentration range from 1.0-10.0 $\mu \mathrm{g} \cdot \mathrm{ml}^{-1}$. In this concentration range luteolin obeys Lambert-Beer's law with the following regression equation: $\mathrm{A}=0.18 \mathrm{c}-0.003(\mathrm{r}=0.9999)$. The content of total flavonoids, estimated as luteoiln, was determined in the samples of herbal drugs as well as in ether and ethylacetate extracts of wild Thymus species. The obtained results are presented in Table 2. coefficient of correlation are the following: area $=3.6884 \cdot 10^{5}$ $m$ (luteolin), $R S D=3.67 \%, r=0.9991$. The accuracy of the method was checked by the method of standard additions which showed a satisfactory accuracy (21), whereas the sensitivity of the method was determined by construction of a calibration curve in the low concentration region (0.1-1.0 $\mu \mathrm{g})$ approximated as a detection and quantification limit. The regression equation of this curve was:

area $=4.1182 \cdot 10^{5} \mathrm{~m}$ (luteolin) with $S D=10802$ and $r=0.9979$. The limit of detection calculated as three times the ratio between the $S D$ and the slope of the low concentration curve (DL =

Table 2. The content of total flavonoids in different samples of Thymus determined by spectrophotometry: drug samples $\left(\mathrm{A}_{1}\right)$; diethyl-ether extracts $\left(A_{2}\right)$ and ethylacetate extracts $\left(A_{3}\right)$

\begin{tabular}{|c|c|c|c|c|}
\hline & Sample & $\mathrm{A}_{1}(\%)$ & $\mathrm{A}_{2}\left(\mathrm{mg} \cdot \mathrm{ml}^{-1}\right)$ & $\mathrm{A}_{3}\left(\mathrm{mg} \cdot \mathrm{ml}^{-1}\right)$ \\
\hline 1. & Thymus tosevii ssp. tosevii var. tosevii Vel. & 0.07 & 201.3 & 117.5 \\
\hline 2. & Thymus tosevii ssp. tosevii var. longifrons Ronn. & 0.08 & 52.5 & 91.25 \\
\hline 3. & Thymus tosevii ssp. tosevii var. degenii Ronn. & 0.10 & 128.8 & 52.5 \\
\hline 4. & Thymus macedonicus (Deg. et Ur.) Ronn. & 0.11 & 101.3 & 71.88 \\
\hline 5. & Thymus moesiacus Vel. & 0.08 & 244.4 & 64.6 \\
\hline 6. & Thymus alsarensis Ronn. & 0.13 & 240.6 & 48.7 \\
\hline 7. & Thymus longidens var. lanicaulis Vel. & 0.05 & 164.4 & 84.4 \\
\hline
\end{tabular}

Low contents of total flavonoids can be noticed in each of the examined samples, ranging from 0.05 to $0.13 \%(\mathrm{~m} / \mathrm{m})$. The fraction of flavonoids that passed into ether or ethylacetate extract is variable, but for most of the samples ether extracts contain a larger quantity of flavonoids (except for $T$. tosevii var. longifrons). This is probably due to the fact that Macedonian Thymus species contain many more free flavone aglycones in comparison to the content of glycosides.

\section{HPLC determination of luteolin and total flavonoids}

The HPLC screening analysis of extracts obtained after hydrolysis (extract B) showed that the main flavone component in the samples of Thymus is luteolin (Fig. 1). As for the other components having UV spectra of flavonoids, the peaks due to apigenin had a significantly smaller area compared to that obtained for luteolin. The previously developed and validated procedure for determination of luteolin (21) was adopted for quantitative analysis of luteolin in Thymus extracts, as well. The calibration curve of luteolin was made in the concentration range of $0.05-1 \mathrm{mg} \cdot \mathrm{ml}^{-1}$, or expressed in terms of mass of luteolin injected into the column, from 1-20 $\mu$ g luteolin. The linear dependence of the mass of luteolin injected in the column was established in the whole range. The linear regression equations obtained at $348 \mathrm{~nm}$ with the corresponding RSD values and the
3.SD/slope) was found to be $0.09 \mu \mathrm{g}$, whereas the limit ofquantification calculated as ten times the same ratio $(\mathrm{QL}=$ 10.SD/slope) (22) was found to be $0.26 \mu$ g of luteolin.

The results from the determination of luteolin in samples of wild Thymus spp. from different regions from Macedonia are presented in Table 3. The content of luteolin as well as the content of total flavonoids in air dried material is found to be $0.23-0.48 \%(\mathrm{~m} / \mathrm{m})$ and $0.26-0.52 \%(\mathrm{~m} / \mathrm{m})$, respectively.

Comparing the HPLC results to those obtained by spectrophotometry, significant differences in the obtained data can be noticed. These results imply that the spectrophotometric determination of total flavonoids achieves only $16-27 \%$ of the total amount of flavonoids obtained by the HPLC method. This makes the spectrophotometric method with $\mathrm{AlCl}_{3}$ unfavorable for use in the determination of total flavonoids in Thymus species. The present work offers a HPLC method for the determination of luteolin content in the herbs of wild Thymus, which can be used in routine analysis of the drug. If other flavonoids are present, they can be quantified as individual, or as total flavonoids. The proposed method is the more important because of the lack of methods for quantification purposes in the available literature. 
Table 3. The content of luteolin and total flavonoids in samples of wild growing Thymus determined by HPLC (in \%)

\begin{tabular}{clcc}
\hline \hline & Samples & $\omega$ (luteolin) & $\omega$ (total flavonoids) \\
\hline 1. & Thymus tosevii ssp. tosevii var. tosevii Vel. & 0.39 & 0.47 \\
2. & Thymus tosevii ssp. tosevii var. longifrons Ronn. & 0.43 & 0.47 \\
3. & Thymus tosevii ssp. tosevii var. degenii Ronn. & 0.37 & 0.40 \\
4. & Thymus macedonicus (Deg. et Ur.) Ronn. & 0.48 & 0.52 \\
5. & Thymus moesiacus Vel. & 0.44 & 0.50 \\
6. & Thymus alsarensis Ronn. & 0.48 & 0.49 \\
7. & Thymus longidens var. lanicaulis Vel. & 0.23 & 0.26 \\
\hline
\end{tabular}

\section{Conclusion}

Two methods for the determination of flavonoids in wild Thymus species from Macedonian flora were applied: spectrophotometric with $\mathrm{AlCl}_{3}$ and HPLC. The content of total flavonoids in air dried plant material determined by spectrophotometric method ranged from $0.05-0.13 \%$, calculated as luteolin. The content of total flavones, expressed as luteolin as the main flavone present, determined by HPLC ranged from 0.26-0.52\%. According to the obtained results, UV spectrometric determination achieved only $16-27 \%$ of the total amount of flavonoids obtained by HPLC. That makes the HPLC method highly recommended for use in the determination of flavonoids in Macedonian Thymus species.

\section{References}

1. V.O. Van Den Broucke, Fitoterapia, 54, 171-174 (1983)

2. V.O. Van Den Broucke and J.A. Lemli, Pharmaceutisch Weekbiad Scientific Edition, 5, 9-14 (1983)

3. J. Cabo, M. E. Crespo, J. Jimenez and A. Zarzuelo, Plan. Med. et Phytother., 20, 213-218 (1986)

4. Abdel-Sattar, V. Bankova, A. Kujumgiev, A. Gaklabov, A. Ignatova, C. Todorova and S. Popov. Pharmazie, 50, $62-65$ (1995)

5. G. Aras and G. E. Grella, J. Horticul. Sci., 67, 197-202 (1992)

6. N. Nakatani, ACS Symposium series, 507, 72-86 (1992)
7. N. Deighton, S.M. Glidewell, B.A. Goodman and S.G. Deans. Proceedings of the Royal Society of Edinburg Section B - Biological Science, 102, 247-252 (1994)

8. Banias, V. Oreopoulou and C. D. Thomopoulos, J. Am. Oil. Chem. Soc., 69, 520-524 (1992)

9. K. Miura and N. Nakatani, Agric. Biol. Chem., 53, 3043-3045 (1989) 10. T. Adzet, R. Vila and S. Canigueral, J. Ethnopharmacol., 24, 147-154 (1988) 11. L. Hernandez, F. A. T. Barberan and F. T. Lorente, Bio. Syst. Ecol., 15, 61-67 (1987)

12. F. A. T. Barberan, L. Hernandez, F. Ferreres, T. Tomas, Plant. Med., 57, 452-454 (1985)

13. F. Ferreres, F. Tomas, F. A. T. Barberan and L. Hernandez, Plant. Med. et Phytother. 19, 89-97 (1985)

14. T. Adzet and F. Martinez, Bio.Syst. Ecol. 9, 293-295 (1981)

15. F. A. T. Barberan, S. Z. Husain and M. I. Gil, Bio. Syst. Ecol., 16, 43-46 (1988)

16. S. Kulevanova, M. Stefova and T. Stafilov, Pharmazie 55, 391-2 (2000)

17. S. Kulevanova, M. Stefova and T. Stafilov, Acta Pharm., 50, 29-37 (2000)

18. S. Kulevanova, T. Stafilov, F. Anastasova, M. Ristic and D. Brkic, Pharmazie 52, 886-888 (1997)

19. T. J. Mabry, K. R. Markham and M. B. Thomas, The Systematic Identification of Flavonoids, Springer-Verlag, New York-Heidelberg-Berlin, 1970.

20. Pharmacopoeia Helvetica editio septima, Eidgenossiche drucksachen und Materializentrale, 3000 Bern, 1987.

21. S. Kulevanova, M. Stefova, Gj. Stefkov and T. Stafilov, J. Liquid Chro. \& Rel. Techolog., 24 (4), 589-600 (2001)

22. Reviewer Guidance, Validation of Chromatographic Methods, Center for Drug Evaluation and Research (CDER), FDA, 1994. 


\title{
Резиме
}

\section{Определување флавони во Thymus видови (Lamiaceae ) од флората на Р. Македонија}

\author{
Светлана Кулеванова ${ }^{1}$, Марина Стефова², Татјана Кадифкова Пановска ${ }^{1}$, \\ Јасмина Тониќ ${ }^{1}$, Трајче Стафилов ${ }^{2}$

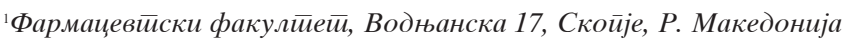

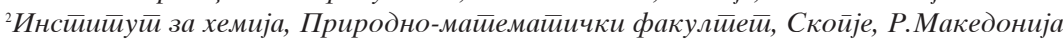

Клучни зборови: Thymus, флавони, идентификација, определување, HPLC анализа

Извршена е анализа на флавоните во екстракти добиени од седум Thymus видови (Lamiaceae) од Македонија, која опфаќа нивна идентификација и квантитативно определување. Екстракти добиени со постапка на хидролиза на суви надземни делови на растенијата се анализирани со хроматографија на тенок слој (TLC) и течна хроматографија под висок притисок (HPLC). Лутеолинот и апигенинот се сепарирани и се идентификувани во споредба со соодветни автентични стандардни супстанции. Содржината на вкупни флавоноиди во дрогите, определена co UV-Vis спектрометрија, користејќ́ $\mathrm{AlCl}_{3}$, се движи во граници од 0,05-0,13 \%. Содржината на флавоноидите во етерните екстракти се движи од 52,5 до 244,4 mg/ml, додека во етилацетатните екстракти е во граници од 48,7-117,5 mg/ml. За квантификација на лутеолинот употребен е претходно развиен и валидиран НРLС метод, користејќи реверзно фазна колона С18, мобилна фаза составена од 5 \% оцетна киселина и метанол со градиентно елуирање и температура на колоната од $40^{\circ} \mathrm{C}$. Содржината на вкупниот лутеолин во дрогите е во граници од 0,23-0,48 \% (m/m), додека содржината на вкупни флавоноиди е $0,26-0,52 \%$. 